\title{
Potential maps for the hydrogeologic prerequisites of the installation of deep geothermal doublets and groundwater source heat pump systems in Budapest, Hungary
}

\author{
Judit Mádl-Szőnyi*, Magdolna Virág, Ferenc Zsemle \\ Department of Physical and Applied Geology, Eötvös Loránd University, Budapest, Hungary
}

Received: January 28, 2015; accepted: January 28, 2015

\begin{abstract}
Budapest is famous for its thermal springs and spas and outstanding thermal water resources. In the $21^{\text {st }}$ century renewable energy utilization - including the use of geothermal energy - became the focus of interest. Improving the use of the different forms of geothermal energy requires the assessment of their possibilities. The potential for deep geothermal doublet systems for direct heating in Budapest was evaluated based on the temperature conditions, the depth and reconnaissance of the carbonate reservoir. NW Buda is not appropriate for thermal water exploration. SW and SE Budapest have better temperature conditions but the lithology of the reservoir is uncertain. Beneath Pest the thermal water is well exploitable. It is obvious from the map of the region that the area is promising; however, due to the hydraulic continuity of the system, reinjection is desirable. Considering the reliability of the employed data the geothermal potential map is suitable only for general orientation and guidance.

The geothermal potential map for Groundwater-sourced Heat Pump Systems (GHPS; scale = $1: 40,000)$ was assembled by evaluating the thickness and appearance of the gravel strata and water table, complemented by the sulfate content as an aggressive component of groundwater. The original geothermal potential map series can be used for the evaluation of potential sites in Budapest. It can be concluded that the Buda side of the Danube River is almost entirely unsuitable for shallow groundwater-based heat pump installations. The only areas under consideration are Óbuda and the riverbanks. On the Pest side, there is no gravel in the central part; the largest areas close to the river and in the immediate surroundings are uncertain, with patches of suitable and possible categories. The southern and eastern area of Pest is the most prospective for GHPS installation. The potential maps only consider natural parameters; however, installation may be strongly influenced by the urbanization and the city environment.
\end{abstract}

Keywords: geothermal potential, deep geothermal doublet, Groundwater-sourced Heat Pump System (GHPS), Budapest, Hungary

\footnotetext{
* Corresponding author: Pázmány Péter sétány 1/C, H-1117 Budapest, Hungary;

E-mail: madlszonyi.judit@gmail.com
} 


\section{Introduction and goals}

Budapest is famous for its thermal springs and spas. The city is characterized by the two geographically different regions of Buda and Pest. The thermal water resources of the city are outstanding. The use of the thermal waters of the city dates back to the Roman and Turkish occupation, in the $2^{\text {nd }}$ and $16^{\text {th }}$ century, respectively. From the 1920s on apartment buildings next to the Danube were heated by thermal water exploited from a deep well on Margaret Island. In the first part of the 20th century the water of the famous Városliget well (Zsigmondy 1878) was used to heat the buildings of the nearby zoo. The heat potential of thermal water can hopefully be used more widely in the future for heating and cooling purposes.

In the $21^{\text {st }}$ century renewable energy - including the use of geothermal energy has become of great interest. Improvement in the different forms of geothermal utilization requires the assessment of its possibilities, taking into consideration both the natural and the artificial factors that can influence the installations. The development of the concept and methodology of the so-called geothermal potential maps are now unfolding worldwide (Coolbaugh et al. 2002; Kohl et al. 2003; Agemar et al. 2007; Odenka et al. 2007; Schillereff 2008; Nam and Ooka 2011; Cullin et al. 2012, etc.). In the case of the Hungarian capital, Budapest, two types of geothermal resources were assessed within the framework of this study: deep geothermal resources that can be utilized by well-doublets drilled into the carbonate basement rocks, and shallow groundwater resources of the Danube gravel terraces that are useable with open loop heat pump systems. For the present research only natural factors, namely hydrogeologic ones, were considered.

\section{Geologic and hydrogeologic settings and possibilities for geothermal utilization}

Budapest is situated at the northeastern edge of the Transdanubian Range, located in the central part of the Pannonian Basin (Fig. 1). The geologic boundaries of the range are tectonic lines: the Rába Line in the NW, the Diósjenö Line in the N and the Balaton Line in the S. The system is made up of slightly metamorphosed Hercynian rocks overlain unconformably by Alpine sequences. The latter consist of Late Permian to Cretaceous sediments made up mainly of Triassic carbonates and mixed carbonates and siliciclastics. The structural setting of the unit is dominated by large NE-SW synforms and antiforms brought about by Mid-Cretaceous tectogenesis (Haas 2001). The unit was emplaced into its present position as a result of large-scale strike-slip movements during the Early Paleogene (Kázmér and Kovács 1985). The Pannonian Basin is a Neogene structure formed as a result of extension-related thinning of the lithosphere in Early to Late Miocene times (Royden and Horváth 1988). In the latest Miocene, inversion of the basin began and contributed to the uplift of certain basement blocks like the Transdanubian Range. Due to the 


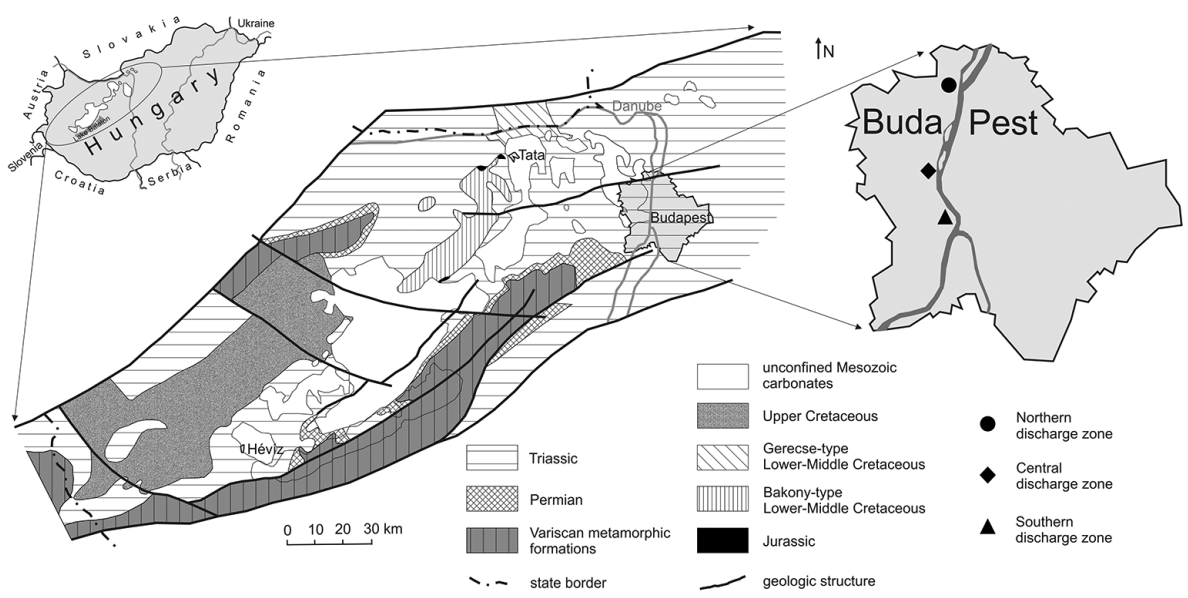

Fig. 1

Transdanubian Range Unit: distribution of Paleozoic-Mesozoic formations (modified after Fülöp in Haas 2001)

attenuated lithosphere, the entire Pannonian Basin is characterized by elevated heat flux $\left(\sim 100 \mathrm{~mW} / \mathrm{m}^{2}\right)$ compared to the surrounding regions (Lenkey et al. 2002; Horváth et al. 2015).

The Transdanubian Range with its $>10000 \mathrm{~km}^{2}$ area is the largest karstified carbonate aquifer system of Hungary (Csepregi 2007). The natural discharge of the system is manifested as cold, lukewarm and thermal springs and wetlands, creeks and rivers as well as upward vertical leakage through the overlying clastic sedimentary formations. One of the main discharge regions of the system can be found in the area of Budapest. This perennial discharge region is in hydraulic connection with the whole system to the W-SW (Fig. 1). In Buda the carbonate reservoir is partly unconfined while beneath Pest it is deep-seated and confined. The discharge zone of the system is concentrated in the surroundings of the Danube which is the base level of erosion, and is situated within the city districts, today a fully urbanized environment. The northern discharge zone is characterized by lukewarm springs $\left(18-22^{\circ} \mathrm{C}\right.$, TDS: $<1000 \mathrm{mg} / \mathrm{l})$, in the central zone by lukewarm $\left(21-27{ }^{\circ} \mathrm{C}\right.$, TDS: $\left.<1000 \mathrm{mg} / \mathrm{l}\right)$ and thermal springs $\left(50-63^{\circ} \mathrm{C}\right.$, TDS: $\left.>1000 \mathrm{mg} / \mathrm{l}\right)$, while in the southern part of the system thermal springs discharge (with $33-45^{\circ} \mathrm{C}$ and TDS: $1500-2000 \mathrm{mg} / \mathrm{l}$; Papp 1942; Alföldi et al. 1968). From the second half of the $19^{\text {th }}$ century on, the use of natural springs has been substituted progressively by deep wells. The thermal water from the discharge region of any regional flow system in a carbonate reservoir can be used for geothermal purposes by deep wells.

The vertical neotectonic deformation of the Pannonian Basin resulted in subsiding lowlands, with on-going accumulation of alluvial sediments even recently. This process has also been proven by high precision GPS measurements and seis- 
mic data (Fig. 2; Horváth and Cloetingh 1996; Grenerczy et al. 2000; Tóth et al. 2002). In the mountainous and hilly areas, several geomorphic levels, such as terrace horizons show the uplift of these areas (Ruszkiczay-Rüdiger et al. 2005). Terrace formation along the Danube was the result of the uplift of the Transdanubian Range coupled with significant climate changes. As a consequence, periodic terrace carving, valley widening and terrace aggradation occurred (Pécsi 1959; Pécsi 1996; Ruszkiczay-Rüdiger et al. 2005). Near-surface gravel terraces in most cases are suitable for the installation of Groundwater-sourced production-injection Heat Pump Systems (GHPS). In such hydrogeologic situations not only the adequate yield but also the possibilities of reinjection, ensuring the sustainability of the system, are provided. These gravel formations of the Danube are abundant in the area of Budapest (Fig. 2) and possess suitable properties to have water source heat pump systems installed in them.

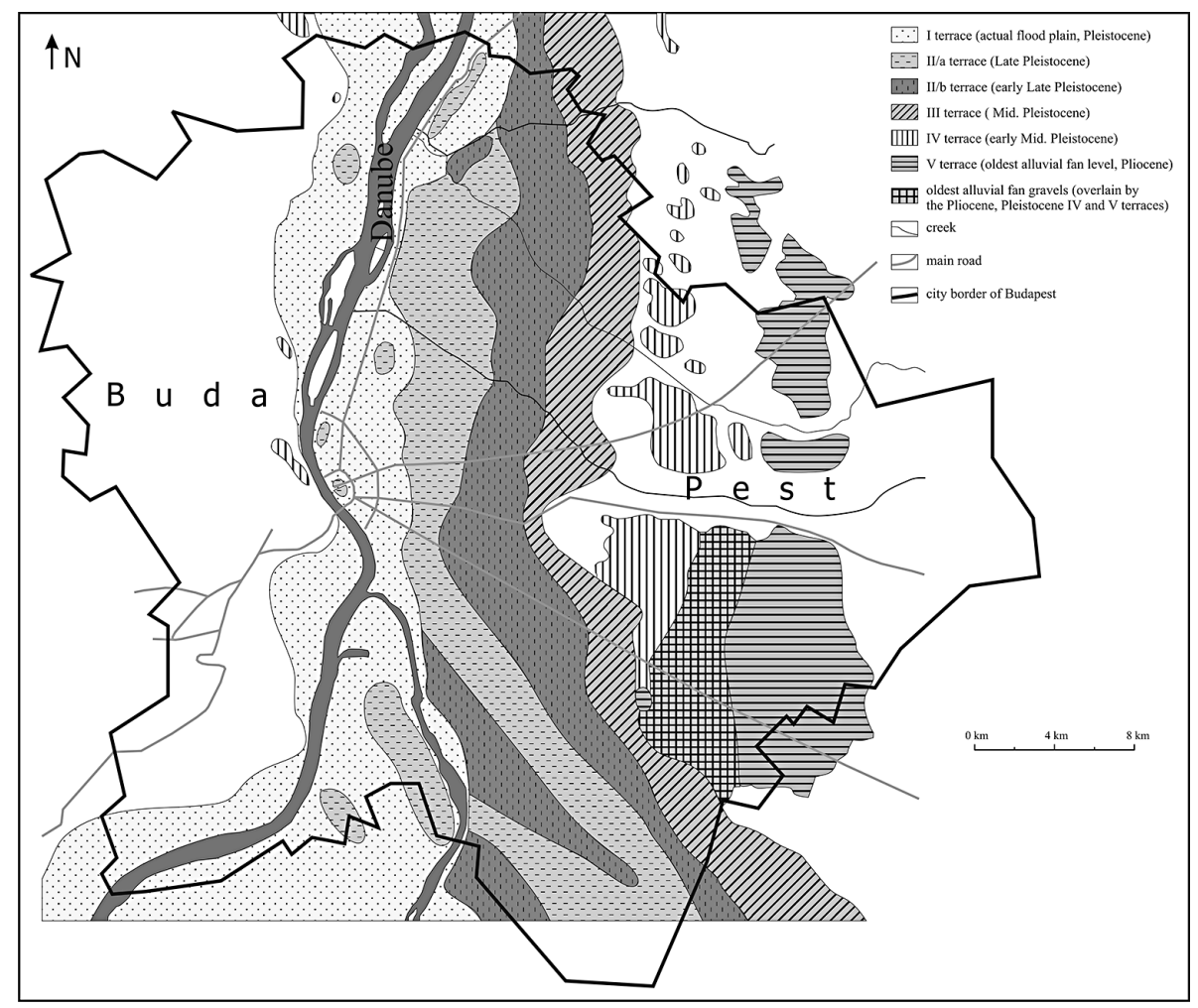

Fig. 2

Danube terraces at Budapest (modified after Pécsi 1959) 


\section{Map for installation of deep geothermal doublets}

\section{Concept of the map}

The aim of the present study was to investigate the possibilities of implementation of heating systems in Budapest, utilizing the thermal water reservoirs in carbonate formations. During the potential-mapping only those factors could be taken into consideration for which data were available in map format, covering the entire area of the city. Thermal water can be exploited from Middle Triassic (Budaörs Dolomite Formation) and Upper Triassic fractured karstic basement formations [Mátyáshegy Formation, Main Dolomite (Hauptdolomit), Dachstein Limestone] and the hydraulically-connected Upper Eocene to Lower Oligocene (Buda Marl) formations.

\section{Data sources and scale of the evaluation}

In the area of Budapest, there are no published detailed maps available showing the presence and thickness of the Eocene thermal water reservoirs. Therefore we could only focus on the Triassic basement (karstic reservoir) when compiling the potential maps for installation of geothermal doublet systems. However even the reliability of the information regarding the thickness of the Triassic reservoir is rather poor. We had to use the 1:500,000 scale map of the basement (Fülöp and Dank 1987) even though it has a lower resolution than what the purposes of this study would require, and its contents are partly outdated. It should also be mentioned that since the completion of the geothermal potential map in 2009, a new Pre-Cenozoic basement map of Hungary was released (Haas et al. 2010). During the GIS derivations, beside this above-mentioned map, the 1:100,000 scale basement, temperature and depth maps (Lorberer 1984, 2003) were used. These maps are generally considered to be the best estimate and they were used for designing the energy and balneology use of Budapest's thermal waters. These maps were accessible in the form of unpublished reports (Lorberer 2002). We are fully aware of the fact that the process of georeferencing and use of maps of different origin and scale was a source of error. It is also obvious that the accuracy is better for those parameters which were estimated on the basis of higher-resolution source maps.

\section{Evaluation of the parameters}

For the geothermal potential evaluation, basement rock composition, temperature and depth categories were determined. The final potential map was derived from the combination of these categories. The generalized version of the map is shown in Fig. 3.

The first factor during the evaluation was the outflow temperature of water. Three categories were used: waters of temperature below $30{ }^{\circ} \mathrm{C}$ were not considered as thermal waters (based on Hungarian regulations); while waters characterized by temperatures higher than $70{ }^{\circ} \mathrm{C}$ were qualified as appropriate for geothermal 


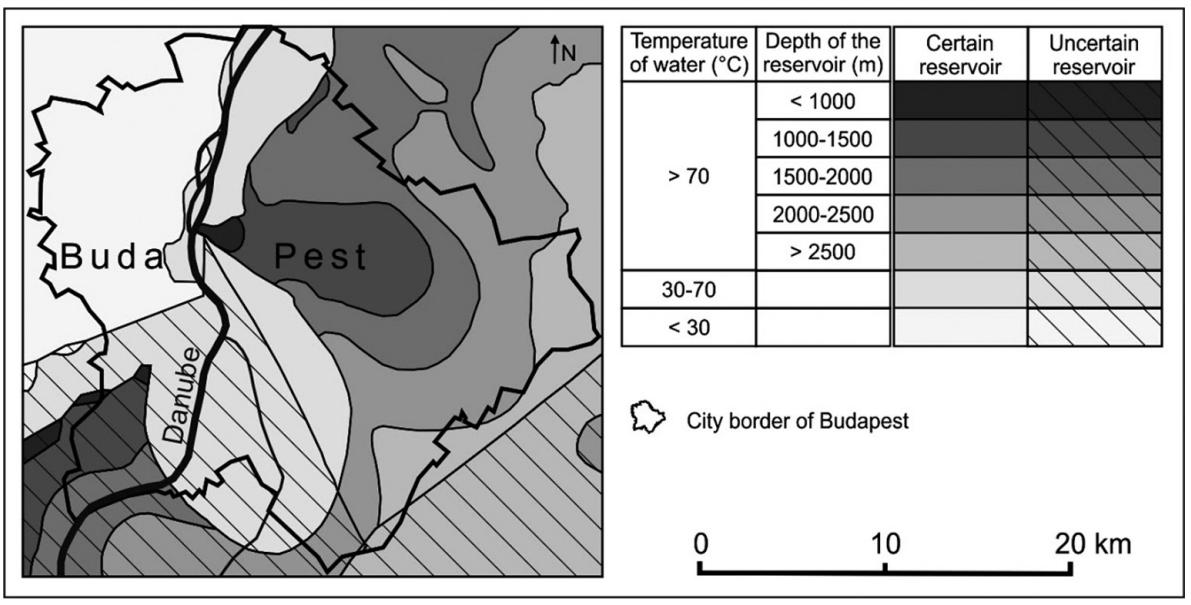

Fig. 3

Geothermal-potential map for the heat utilization of thermal water of the Triassic carbonate basement reservoir

heating with doublet systems. Further evaluation was carried out for those reservoirs characterized by higher than $70^{\circ} \mathrm{C}$ exploitable water, based on the depth of the reservoir. Finally the uncertainty of the reconnaissance of the reservoirs was evaluated by two categories such as for certain and uncertain reservoirs. The geothermal potential map was derived based on the above considerations (temperature of water, depth of the reservoir, and uncertainty of the reservoir) and the final categories of the map display these differences in a direct way (Fig. 3).

\section{Results and Conclusions}

The differences regarding thermal water exploitation possibilities between Buda and Pest are reflected in the map (Fig. 3). NW Buda is not appropriate for thermal water exploitation. Although SW-SE parts of Budapest have better temperature conditions, because of the uncertainties in the lithology of the reservoir this area is not considered as prospective. Beneath Pest the thermal water is well exploitable. The depth to the reservoir and the potential for installation of geothermal doublets increases toward the east. It is obvious from the geothermal potential map of the region that the area is promising for geothermal installation for heating purposes. In Pest the most prospective area with the highest temperatures $\left(>70^{\circ} \mathrm{C}\right)$ and the shallowest reservoir is situated near the Danube. It is indicated in black on the map.

Considering the accuracy of the used data, the generalized geothermal potential map (Fig. 3) is only suitable for general orientation and guidance. The insufficient information on the Triassic basement formations and the constraint of disregarding 
the tectonic structures cause limitations in the use of the map. Groundwater movement within the reservoirs is influenced by fluid potential and fostered by tectonic structures; therefore the success of a newly-established well depends strongly on whether it hits a karstified, fractured zone. The fluid content and the flow conditions in the reservoirs were also neglected during the evaluation. These limitations mean that this map provides only a general overview of the deep geothermal possibilities of the Hungarian capital.

\section{Hydrogeologic factors influencing GHPS installations}

\section{Concept of the evaluation}

The main factors in the assessment of installation of GHPS are shallow geology and the hydrogeologic setup. Groundwater source heat pump systems are most suitable in areas with shallow gravel terraces (Fig. 2). In these areas there is appropriate water yield and the conditions of reinjection are also provided. Design of the GHPS is based on parameters (volume discharge, well spacing, temperature, etc.) which were all taken into consideration with factors of the potential maps. Wells established for family homes range from 5 to $15 \mathrm{~m}$ depth. Greater depths are not economic. A minimum of $50 \mathrm{l} / \mathrm{min}$ volume discharge is necessary with the production and reinjection wells placed at a minimum of $15 \mathrm{~m}$ distance from each other. The distance between individual systems should be a minimum of $30 \mathrm{~m}$. Systems designed for larger office buildings and shopping malls that have greater heating requirements than family dwellings use wells drilled deeper than $15 \mathrm{~m}$. For these, the appropriate well distance is determined by modeling. Water at temperatures below $25^{\circ} \mathrm{C}$ is utilized by GHPS and the energy is extracted by heat exchangers with a maximum of $5{ }^{\circ} \mathrm{C}$ cooling to the already used water. The most desirable temperature is around $12{ }^{\circ} \mathrm{C}$. In this way it can be used both for heating and cooling. Knowledge of the chemical composition of the water is important to be able to prevent corrosion and/or scaling. This study investigates the possibilities of well installation for family dwellings, with a maximum of 13-15 $\mathrm{m}$ depth for the area of Budapest.

\section{Data sources}

The main data source of the study were the thematic maps of the Budapest Engineering Geology Map Series (scale =1:20,000; 1:40,000). Predominantly areas with gravel formations were assessed, as these are the ones where production may be economically feasible and reinjection can be done passively, without extra energy investment. The location of the gravel formations was taken from the "Gravel spread and thickness" map (Raincsák-Kosáry, 1985) by digitalization.

Another important criterion beside gravel thickness is groundwater depth from the surface. The 1:40,000 scale "Depth to the water table" maps by Raincsák-Kosáry 
(1985) provide information on the average groundwater depth. Although this map was made more than 20 years ago, it is still the best comprehensive detailed map covering the entire area of the city. Depth of the gravel from the surface was determined by using the 1:10,000-scale borehole network map of Budapest. A number of chemical components may affect the success of GHPS installation. Because of the lack of any additional data only the sulfate concentration was considered. The evaluation was based on the "Sulfate content of water map" (scale $=1: 40,000$ ) by Raincsák-Kosáry (1985).

\section{Evaluation process and individual parameter maps}

As a first step category maps were compiled for each of the influencing factors of GHPS installation. The individual parameter maps were then used to produce the final potential maps with GIS derivations. The resulting maps were compiled at 1:40,000 scale (ArcView GIS 3.3 software, data processing by M. Virág). In this paper only the generalized versions of the maps are presented (the original maps can be found archived at the Hydrogeology and Geothermics Group of the Department of Physical and Applied Geology of Eötvös Loránd University, Budapest).

The sulfate aggressiveness parameter map displays two categories: under and over $200 \mathrm{mg} / \mathrm{l}$ concentration. This boundary value was selected based on empirical considerations and from the experience of operating heat pump systems. Higher than 200 $\mathrm{mg} / \mathrm{l}$ sulfate concentration is considered as an inhibiting factor due to the increased possibility of corrosion (Fig. 4). The map of sulfate content displays a patched pattern for both Buda and Pest.

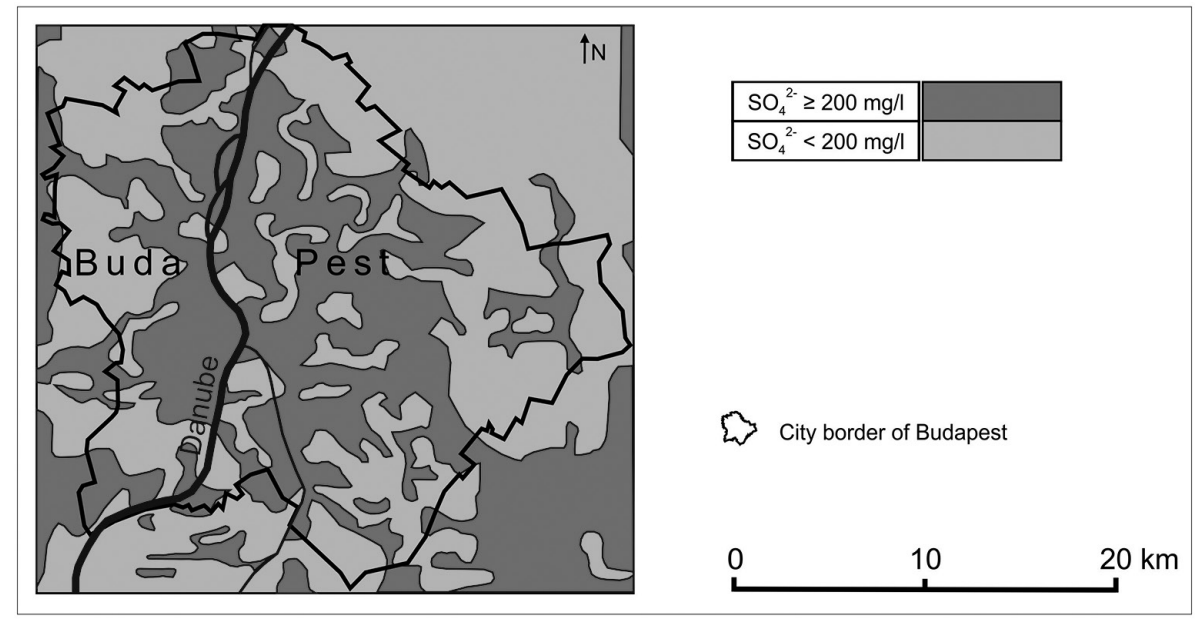

Fig. 4

Sulfate content map of shallow groundwater 
For the gravel thickness map (Fig. 5) four categories were distinguished: areas with no gravel, 0 to $5 \mathrm{~m}, 5$ to $10 \mathrm{~m}$, and over $10 \mathrm{~m}$ gravel thickness. Considering the system requirements, a minimum of $5 \mathrm{~m}$ gravel thickness was defined as necessary for the installation of GHPS. In the areas that fall into one of the last two categories the systems can be installed at lower cost and higher capacity. As family dwellings do not use wells below $15 \mathrm{~m}$, a gravel thickness greater than this does not further improve the efficiency (Fig. 5). The gravel thickness map reflects the distribution of the Danube terraces. In Buda we can find gravel only close to the river however in Pest there are large areas with sufficient gravel thickness.

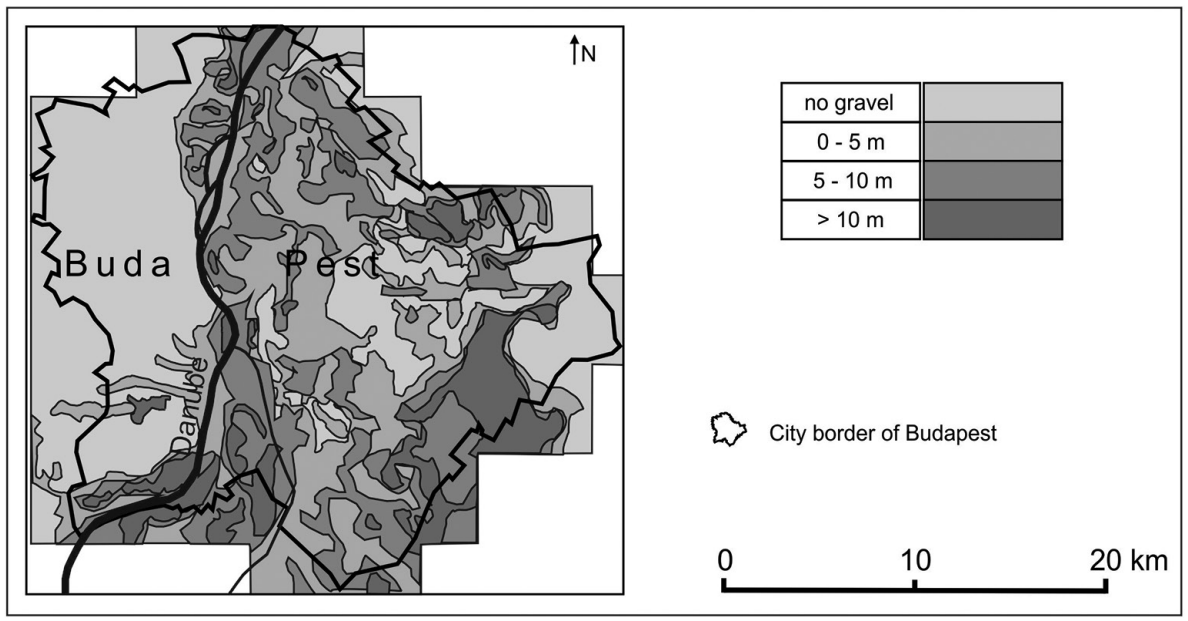

Fig. 5

Gravel thickness map

The depth of occurrence of the exploitable gravel layer is another important factor investigated by this study, as it influences the feasibility. In the map the areas without gravel (no gravel category of Fig. 5) were excluded. Also, situation can occur where the otherwise sufficiently thick gravel layer is buried too deeply. Where the top of the gravel layer is below $13 \mathrm{~m}$ depth, the area is qualified as not suitable, as a minimum of $1 \mathrm{~m}$ water column needs to be in the well, and the pump should be clear of the bottom $1 \mathrm{~m}$ of the borehole - with these, the $15 \mathrm{~m}$ depth limit is reached. According to Fig. 6, gravels in Pest generally occur within the first $8 \mathrm{~m}$ below the surface with the exception of the area in the middle-eastern part of Pest where there is no gravel.

The depth to the water table was also evaluated with five categories from 0 to $1 \mathrm{~m}$ to over $13 \mathrm{~m}$ (Fig. 7). The pattern of water table map reflects the distance from the river and creeks and generally shows greater water table depth with greater distance. Those areas characterized by shallow groundwater ( 0 to $1 \mathrm{~m}$ below the surface) were excluded during the final geothermal potential derivation, as reinjection would be problematic under such circumstances (Fig. 7). 


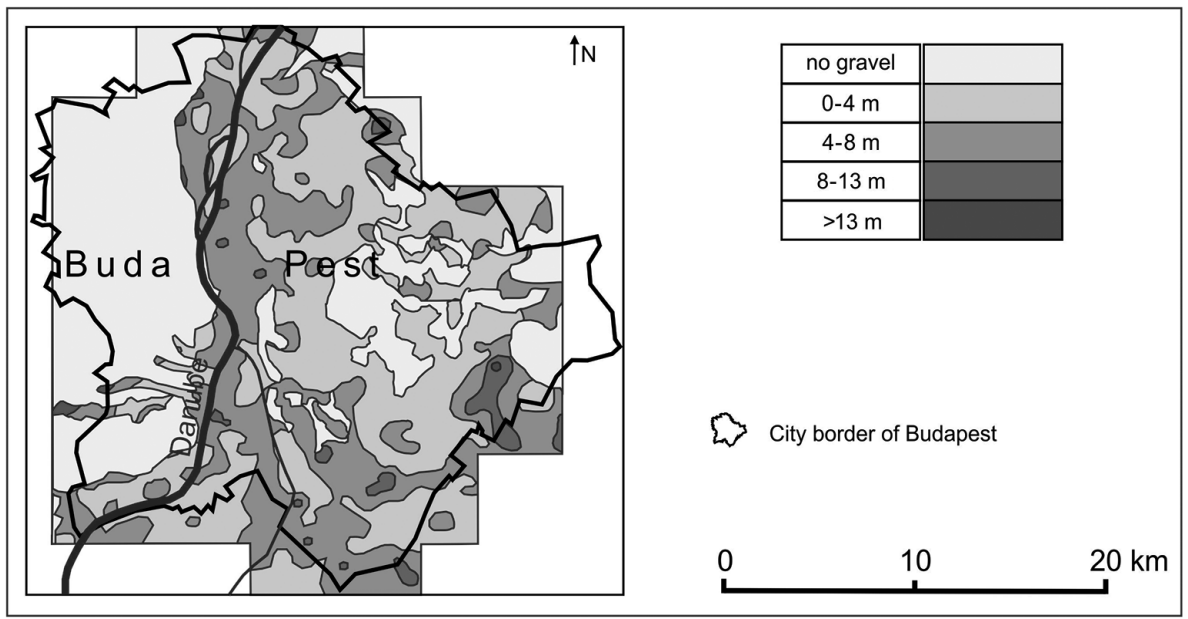

Fig. 6

Occurrence depth of gravel layer

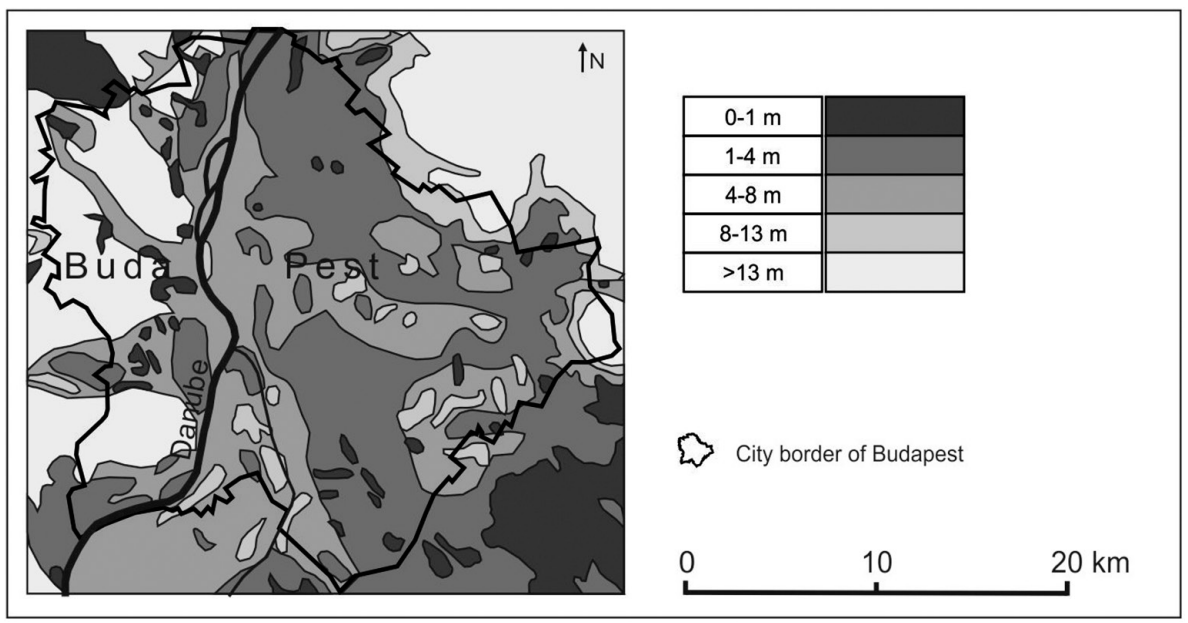

Fig. 7

Average depth to the water table

\section{Derivation of the final geothermal potential map}

After compiling the individual parameter maps, the derivation of the final geothermal potential map was based on a matrix system taking into consideration the depth of the occurrence of gravel strata ( 0 to $4 \mathrm{~m}, 4$ to $8 \mathrm{~m}, 8$ to $13 \mathrm{~m}$, over $13 \mathrm{~m}$ ), the 
average depth to groundwater table ( 0 to $1 \mathrm{~m}, 1$ to $4 \mathrm{~m}, 4$ to $8 \mathrm{~m}, 8$ to $13 \mathrm{~m}$, over $13 \mathrm{~m}$ ), as well as the thickness of the gravel strata ( 0 to $5 \mathrm{~m}, 5$ to $10 \mathrm{~m}$, over $10 \mathrm{~m}$ ). From the combination of these factors and their categories, four final empirical categories were derived which characterize the increasing hydrogeologic potential for GHPS installation: unsuitable, uncertain, possible and suitable. Areas without gravel strata appear in the map with no gravel category. The "unsuitable" areas are those where (1) the depth to water table is 0 to $1 \mathrm{~m}$ from the surface, or (2) where the depth of the occurrence of gravel strata is over $13 \mathrm{~m}$ below the surface. The uncertain category indicates the areas where the available data are not sufficient to evaluate the potential. The areas with possible and suitable categories are prospective for GHPS installation but at different grade. The best and most certain category is the suitable one. The areas with over $200 \mathrm{mg} / \mathrm{l}$ sulfate concentrations (corrosion risk) are indicated as additional information for all the derived categories. The final potential map with these categories were derived with the ArcView GIS 3.3 software (Fig. 8). The final geothermal potential map allows for empirical categorization of the different areas. The series of single parameter maps (Figs 5, 6 and 7) give the background for the assessment of the individual installation criteria and the basic parameters of the different areas.

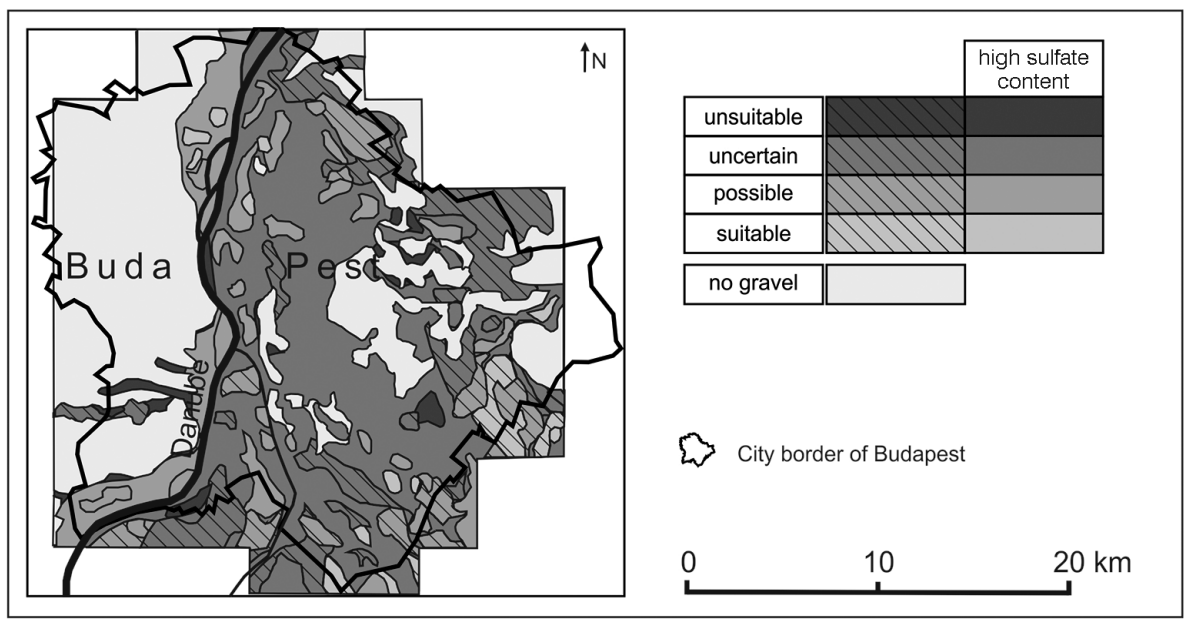

Fig. 8

Geothermal-potential map for hydrogeological prerequisites of the installation of GHPS

The original geothermal potential map of GHPS (Fig. 8) can be used for the assessment of a chosen site, on a minimum 1:40,000 scale with good reliability. However, the map cannot be used in situations where the gravel occurs in the unsaturated zone. The reliability of the used data is fair, with the exception of the 20 -year-old water table maps. Overall, the map is a reliable tool to select the installation sites. 


\section{Results and Conclusions}

It can be concluded that the Buda side is almost entirely "unsuitable" for groundwater source heat pump installations. The only areas worth considering are the foothills, such as Óbuda, and the riverbanks like Lágymányos. With the exception of the "no-gravel" and "unsuitable" section the areas of the Pest side can be used for GHPS installation. The "possible" and "suitable" areas can be found along the Danube on both sides but in the form of patches. Similarly, east of the excluded area in the center of Pest these "possible" and "suitable" patches also occur. The "uncertain" category covers $\sim 60 \%$ of the area of Pest, where further examination is necessary to prove the possibility of GHPS installation. In the southern and eastern parts of Pest the "possible" and "suitable" categories with less than $200 \mathrm{mg} / \mathrm{l}$ sulfate content are the most prospective for GHPS installations (Fig. 8).

A great deficiency of the presented potential map for GHPS is that it only considers natural (hydrogeologic) parameters. Installation may, however, be strongly influenced by the level of urbanization and many components of the urban environment. Since the potential map is intended to serve as a preliminary tool in decision-making, these urbanization-related aspects may play an important role. However, being beyond the scope of the present study, they were not discussed here.

\section{Summary}

Budapest has been famous for its thermal springs and spas throughout its history. Due to the increasing need for renewable energy, the heat potential of thermal waters should be used more intensively in the future.

The potential for the installation of geothermal doublet systems for direct heating in Budapest was evaluated based on the analysis of temperature conditions, depth and reconnaissance of the deep carbonate reservoir. The differences in the hydrogeologic setup between Buda and Pest are reflected in the map. NW Buda is apparently not "suitable" for thermal water production. SW Budapest, in spite of its better temperature conditions, cannot be qualified as more prospective either, because of the uncertainties in the lithology of the reservoir. However, beneath Pest the thermal water is well exploitable. The depth of the reservoir and the potential for exploring for higher-temperature water increases toward the east. It is obvious from the geothermal potential map of the region that the area is promising for the installation of geothermal heating systems.

The hydraulic and temperature behavior of the system - as a consequence of the hydraulic continuity of the entire Transdanubian Range - offers the possibility to use the heat content of the deep carbonate reservoir. However, only with the geothermal doublet systems can the thermal water be sustainably utilized (Mádl-Szőnyi 2014).

The geothermal potential map (original scale of 1:40,000) for GHPS can be used when selecting and evaluating potential sites in the area of Budapest. It is burdened 
by the uncertainty of the groundwater depth maps that are based on 20 year-old data. The final categories of the summarizing map allow for empirical categorization based on potential assessment. The criteria and preparation process can be retraced and the basic parameters for certain areas can be individually studied.

The map shows that in the greater part of Buda there is no gravel, with the exception of the close surroundings of the Danube. Here there are limited areas which may be qualified as "possible" or "suitable" for GHPS installation, surrounded by a larger zone of the "uncertain" category. On the contrary the majority of the Pest side is "uncertain" but there are patches with "suitable" and "possible" categories, as well. Only the higher sulfate content may be a limiting factor; therefore the southern and eastern areas of the city is the most prospective from the point of view of GHPS installations.

The potential map may be of help in decision making for both investors and authorities. It can be reliably used to select installation environments. Anthropogenic influencing factors such as level of urbanization, roads and paved areas are not accounted for because these are beyond the scope of this study.

The paper presents the geothermal-potential maps (made in 2009) in a generalized form. The database and the original maps are available at the Hydrogeology and Geothermics Group of Physical and Applied Geology Department of ELTE in Budapest.

\section{Acknowledgements}

The research was supported by the Budapest Sewage Works Pte Ltd., the Erdélyi Mihály Foundation and OTKA $72590 \mathrm{~K}$ (to Andrea Mindszenty). The long-term activity of Árpád Lorberer in the systematic data collection and evaluation for the Buda Thermal Karst system is highly appreciated. Without his results and maps the derivations for deep geothermal possibilities could not be achieved. The consultations with László Tóth regarding GHPS was also valuable. The authors acknowledge the contribution of many students of the Hydrogeology and Geothermics Group of ELTE in data collection and processing for the compilation of potential maps for GHPS. Andrea Mindszenty, Eszter Pulay, Ádám Tóth and Tímea Havril are also acknowledged for their technical help in editing the text and generalization of the original maps for the goals of this publication. The authors acknowledge the valuable comments and notes of an anonymous reviewer, which helped improve the quality of the manuscript.

\section{References}

Agemar, T., J.A. Alten, K. Kühne, A.A. Maul, S. Pester, W. Wirth, R. Schulz 2007: Development of a Geothermal Information System for Germany. - Proceedings European Geothermal Congress, Unterhaching, Germany. 
Alföldi, L., L. Bélteky, T. Böcker, J. Horváth, K. Korim, P. Liebe, R. Rémi 1968: Budapest Hévizei (Thermal waters of Budapest). - VITUKI, Budapest, 365 p. (in Hungarian)

Coolbaugh, M.F., G.L. Raines, L.A. Shevenell, D.L. Sawatzky, R. Bedell, B.T. Minor 2002: A geothermal GIS for Nevada: defining regional controls and favorable exploration terrains for extensional geothermal systems. - Geothermal Resources Council Transactions, 26, pp. 485-490.

Cullin, J.R., L. Xing, E. Lee, J.D. Spitler, D.E. Fisher 2012: Feasibility of foundation heat exchangers for residential ground source heat pump systems in the United States. - ASHRAE Transactions, 118, pp. 1039-1048.

Csepregi, A. 2007: A karsztvíztermelés hatása a Dunántúli-középhegység vízháztartására (The effect of water withdrawal on the water balance of the Transdanubian Range). - In: Alföldi L., L. Kapolyi (Eds): Bányászati karsztvízszint süllyesztés a Dunántúli-középhegységben (Mining Dewatering in the Transdanubian Range). Geography Institute of Hungarian Academy of Sciences, 138, pp. 77-112. (in Hungarian)

Fülöp, J., V. Dank 1987: Magyarország kainozoikum elhagyásával készített földtani térképe (Geological map of Hungary with the omission of the Cenozoic). - Geological Institute of Hungary. (in Hungarian)

Grenerczy, Gy., A. Kenyeres, I. Fejes 2000: Present crustal movement and strain distribution in Central Europe inferred from GPS measurements. - J. Geophys. Res., 105, pp. 21835-21846.

Haas, J. (Ed.) 2001: Geology of Hungary. - Eötvös University Press, Budapest, p. 317.

Haas, J., T. Budai, L. Csontos, L. Fodor, Gy. Konrád 2010: Magyarország Pre-Kainozoós medencealjzatának földtani térképe (Pre-Cenozoic geological map of Hungary), 1:500000. Geological Institute of Hungary. (in Hungarian)

Horváth, F., S. Cloetingh 1996: Stress-induced late stage subsidence anomalies in the Pannonian basin. - Tectonophysics, 266, pp. 287-300.

Horváth, F., B. Musitz, A. Balázs, A. Végh, A. Uhrin, A. Nádor, B. Koroknai, N. Pap, T. Tóth, G. Wórum 2015: Evolution of the Pannonian basin and its geothermal resources. - Geothermics, 53, pp. 328-352.

Kázmér, M., S. Kovács 1985: Permian-Paleogene paleogeography along the eastern part of the InsubricPeriadriatic lineament system: evidence for continental escaper of the Bakony-Drauzug unit. - Acta Geol. Hung., 28/1-2, pp. 71-84.

Kohl, T., N. Andenmatten-Berthoud, L. Rybach 2003: Geothermal resource mapping example from northern Switzerland. - Geothermics, 32, pp. 721-732.

Lenkey, L., P. Dövényi, F. Horváth, S. Cloething 2002: Geothermics of the Pannonian basin and its bearing on the neotectonics. - EGU Stephan Mueller Special Publication Series, 3, pp. 29-40.

Lorberer, Á. 1984: Budapest környezetének geotermikus térképe (Geothermal map of surroundings of Budapest), 1:100 000. - Manuscript, VITUKI. (in Hungarian)

Lorberer, Á. 2002: A budapesti termálkarszt állapotértékelése (Budapest thermal karst status assessment). - Final report, VITUKI, pp. 1-45. (in Hungarian)

Lorberer, Á. 2003: A Dunántúli-középhegység karsztvízszint térképe, ÉK-rész, 2003. 01. 01-i állapot (Karst water map of the Transdanubian Range NE at 01/01/2003), 1:200 000. - VITUKI, Budapest. (in Hungarian)

Mádl-Szőnyi, J. 2014: Genesis and utilization of thermal flow in deep carbonate systems. - In: Stevanović, Z., N. Kresić N. (Eds): Characterization and Engineering of Karst Aquifers. Springer, in press.

Nam, Y., R. Ooka 2011: Development of potential map for ground and groundwater heat pump systems and the application to Tokyo. - Energy and Buildings, 43/2-3, pp. 677-685.

Odenka, J., M.I. Rüsgen, I. Strober, K. Czurda 2007: GIS-supported mapping of shallow geothermalpotential of representative areas in south-western Germany: possibilities and limitations. - Renewable Energy, 32, pp. 2186-2200.

Papp, F. 1942: Budapest meleg gyógyforrásai (Thermal springs of Budapest). - Budapesti Központi Gyógy- és Üdülőhelyi Bizottság Rheuma és Fürdőkutató Intézet, Budapest, 252 p. (in Hungarian)

Pécsi, M. 1959: A magyarországi Duna-völgy kialakulása és felszínalaktana (Formation and Geomorphology of the Danube Valley). - Akadémiai Kiadó, Budapest, 346 p. (in Hungarian with German summary) 
Pécsi, M. 1996: Geomorphological regions of Hungary. - Geography Institute of Hungarian Academy of Sciences, Budapest, 121 p.

Raincsák-Kosáry, Zs. 1985: Budapest Építésföldtani Térképsorozata (Budapest Engineering Geology Map Series). - Manuscript, Hungarian Mining and Geological Office. (in Hungarian)

Royden, L.H., F. Horváth (Eds) 1988: The Pannonian basin - a study in basin evolution. - Amer. Assoc. Petrol. Geol. Memoir, 45, Tulsa, 394 p.

Ruszkiczay-Rüdiger, Zs., T. Dunai, G. Bada, L. Fodor, E. Horváth 2005: Middle to late Pleistocene uplift rate of the Hungarian Mountain Range at the Danube Bend (Pannonian Basin) using in situ produced 3He. - Tectonophysics, 410, pp. 173-187.

Schillereff, H.S. 2008: Using hydrogeologic data for geoexhange potential mapping, City of Whitehorse, Yukon. - 61st Canadian Geotechnical Conference and 9th Joint CGS/IAH-CNC Groundwater Conference, Edmonton.

Tóth, L., P. Mónus, T. Zsíros, M. Kiszely 2002: Seismicity in the Pannonian Region - earthquake data. In: Cloetingh, S., F. Horváth, G. Bada, A. Lankreijer (Eds): Neotectonics and Surface Processes: the Pannonian Basin and Alpine/Carpathian System.EGU Stephan Mueller Special Publication Series, 3, pp. 9-28.

Zsigmondy, V. (1878): A városligeti artézi kút Budapesten (The artesian well of Városliget, Budapest). Légrády testvérek, Budapest, 86 p. (in Hungarian) 